\title{
Empirical Study on the Impact of Information Disclosure Quality on Listed Companies' Value
}

\author{
_-An Empirical Analysis of China’s Listed Companies from 2013 to 2015 \\ Dongwu $\mathrm{Niu}^{1,}{ }^{*}$ and Heng $\mathrm{Ma}^{2}$ \\ ${ }^{1}$ Nanjing University of Aeronautics and Astronautics, Nanjing 210016, China \\ ${ }^{2}$ Nanjing University of Aeronautics and Astronautics, Nanjing 210016, China \\ niudongwu@163.com
}

\begin{abstract}
Firstly, this paper analyzes the information disclosure status of A-share listed companies in Shenzhen Stock Exchange. Through the statistics and analysis of information disclosure assessment results, it finds out that the information disclosure level of listed companies has been obviously improved. This result shows that relevant rules and regulations of information disclosure implemented in recent years played a certain role. Secondly, using the data from 2013 to 2015 as a sample, taking Tobin's Q value as the surrogate variable of the company's value, the assessment result of the Shenzhen Stock Exchange's information disclosure as the substitute variable of the information disclosure quality, introducing the relevant control variables, establishing regression model to empirically analyze the impact of quality of information disclosure on enterprise value. The results indicate that the quality of information disclosure of listed companies has a positive correlation with the value of the company.
\end{abstract}

Keywords: Information Disclosure Quality; Listed Company; Company Value; Tobin's Q.

\section{Introduction}

China's securities market has experienced so many years of development, the quality of information disclosure of listed companies is directly related to the securities market efficiency, investor protection and other important issues. Coupled with the separation of management and ownership, as well as the asymmetry of information between listed companies and external investors, therefore, it is very important for the healthy development of China's capital market to reasonably guide the disclosure behavior of listed companies, improve the quality of information disclosure and enhance the effective market information.

\section{Theoretical Basis and Analysis}

This paper is based on the theory of information economics, and takes Shenzhen Stock Exchange listed companies as the research object [1]. It mainly studies the relationship between the quality of information disclosure and the value of the company, hoping to get a positive influence on the value of the company. Such result reveals a great practical and theoretical significance for promoting the improvement of information disclosure level, protecting the interests of investors and improving the efficiency of securities market.

\subsection{For enterprises}

If the higher the quality of information disclosure, the greater the value of the enterprise, it will be easier for investors to receive a signal then reduce the uncertainty of investment. At the same time, to a certain extent, it is helpful in reducing the "bad money drive out good money" lemon market effect [2]. In order to maximize profits, enhance corporate image and reduce financing costs, enterprises will adopt appropriate measures to improve the quality of information disclosure, improve corporate governance structure, improve corporate governance efficiency and achieve the company's planning and objectives. 


\subsection{For regulators}

Regulatory departments are the bridge between investors and listed companies. More emphasis on the quality of information disclosure, more measures can be taken. Therefore the efficiency of capital market operation can be improved.

\subsection{For investors}

As with enterprises, investors are also the main participants in the capital market. Although both are essential, lack of effective exchange of information, resulting in the phenomenon of asymmetric information [3]. High level of information disclosure can reduce investment risks and protect investors' interests. The signal transfer theory holds that when information disclosure quality rises to a certain level, it can reduce information asymmetry, information collection cost and transaction uncertainty, and protect the interests of investors.

\section{Empirical research design, Test results and Analysis}

\subsection{An Analysis of the Quality of Listed Companies' Information Disclosure in Shenzhen Stock Exchange}

This paper chooses the companies listed on the Shenzhen Stock Exchange as sample data. Statistics from the 2001-2015 information disclosure quality assessment results, as shown in Table 1.

Table 1 Shenzhen Stock Exchange disclosure of all companies evaluation information

\begin{tabular}{cccccccccc}
\hline Years & Total & \multicolumn{2}{c}{ Excellent(A) } & \multicolumn{2}{c}{ Good(B) } & \multicolumn{2}{c}{ Qualified(C) } & \multicolumn{2}{c}{ Unqualified(D) } \\
\cline { 2 - 9 } & & QTY & PR (\%) & QTY & PR (\%) & QTY & PR (\%) & QTY & PR (\%) \\
2001 & 517 & 30 & $5.80 \%$ & 201 & $38.88 \%$ & 251 & $48.55 \%$ & 35 & $6.77 \%$ \\
2002 & 509 & 40 & $7.86 \%$ & 239 & $46.95 \%$ & 197 & $38.70 \%$ & 33 & $6.48 \%$ \\
2003 & 507 & 41 & $8.09 \%$ & 268 & $52.86 \%$ & 173 & $34.12 \%$ & 25 & $4.93 \%$ \\
2004 & 502 & 30 & $5.98 \%$ & 303 & $60.36 \%$ & 147 & $29.28 \%$ & 22 & $4.38 \%$ \\
2005 & 547 & 55 & $10.05 \%$ & 308 & $56.31 \%$ & 149 & $27.24 \%$ & 35 & $6.40 \%$ \\
2006 & 592 & 59 & $9.97 \%$ & 313 & $52.87 \%$ & 188 & $31.76 \%$ & 32 & $5.41 \%$ \\
2007 & 690 & 66 & $9.57 \%$ & 363 & $52.61 \%$ & 234 & $33.91 \%$ & 27 & $3.91 \%$ \\
2008 & 759 & 80 & $10.54 \%$ & 454 & $59.82 \%$ & 206 & $27.14 \%$ & 19 & $2.50 \%$ \\
2009 & 812 & 97 & $11.95 \%$ & 550 & $67.73 \%$ & 147 & $18.10 \%$ & 18 & $2.22 \%$ \\
2010 & 1168 & 155 & $13.27 \%$ & 806 & $69.01 \%$ & 191 & $16.35 \%$ & 16 & $1.37 \%$ \\
2011 & 1411 & 233 & $16.51 \%$ & 985 & $69.81 \%$ & 169 & $11.98 \%$ & 24 & $1.70 \%$ \\
2012 & 1537 & 243 & $15.81 \%$ & 1082 & $70.40 \%$ & 193 & $12.56 \%$ & 19 & $1.24 \%$ \\
2013 & 1536 & 296 & $19.27 \%$ & 1064 & $69.27 \%$ & 159 & $10.35 \%$ & 17 & $1.11 \%$ \\
2014 & 1618 & 336 & $20.77 \%$ & 1103 & $68.17 \%$ & 147 & $9.09 \%$ & 32 & $1.98 \%$ \\
2015 & 1746 & 360 & $20.62 \%$ & 1136 & $65.06 \%$ & 210 & $12.03 \%$ & 40 & $2.29 \%$ \\
\hline
\end{tabular}

It can be seen that the number of listed companies with "Excellent" and "Good" information disclosure is on the rise. And the proportion of "Qualified" and "Good" fluctuates more obviously with time, while the proportion changes at level A and D are comparatively slower. In general, the overall disclosure level of listed companies in China is in a good trend. The proportional growth of companies with high quality disclosure tends to be moderate and needs to be further improved [4]. At the same time, the trend of deteriorating companies with low quality disclosure must be curbed.

In addition, this article collects data from 1998 when penalties started to be record. The punishment record statistics of Shenzhen Stock Exchange listed companies from 1998 to 2015 is shown in Table 2. The total number of companies punished in 2001 reached a peak with 115 cases, then declined to normal levels year after year. The table shows that the number of companies subject to penalties is slowly declining, but the number of companies subject to penalties is further exacerbated by 2013-2015. 
Table 2 Punished company of Shenzhen Stock Exchange (1998-2015)

\begin{tabular}{cccccc}
\hline $\begin{array}{c}\text { Penalty } \\
\text { category }\end{array}$ & $\begin{array}{c}\text { Public } \\
\text { Years }\end{array}$ & $\begin{array}{c}\text { Notification of } \\
\text { criticism in exchange }\end{array}$ & $\begin{array}{c}\text { Internal } \\
\text { criticism }\end{array}$ & $\begin{array}{c}\text { Notification } \\
\text { of criticism }\end{array}$ & Total \\
\cline { 1 - 4 } & 0 & 1 & 0 & 0 & 1 \\
\hline $\mathbf{1 9 9 9}$ & 0 & 1 & 4 & 0 & 5 \\
\hline $\mathbf{2 0 0 0}$ & 3 & 3 & 11 & 0 & 17 \\
\hline $\mathbf{2 0 0 1}$ & 32 & 0 & 83 & 0 & 115 \\
\hline $\mathbf{2 0 0 2}$ & 21 & 0 & 71 & 0 & 92 \\
\hline $\mathbf{2 0 0 3}$ & 17 & 0 & 63 & 0 & 80 \\
\hline $\mathbf{2 0 0 4}$ & 18 & 0 & 26 & 2 & 46 \\
\hline $\mathbf{2 0 0 5}$ & 33 & 6 & 15 & 1 & 55 \\
\hline $\mathbf{2 0 0 6}$ & 28 & 5 & 5 & 3 & 41 \\
\hline $\mathbf{2 0 0 7}$ & 15 & 22 & 3 & 10 & 50 \\
\hline $\mathbf{2 0 0 8}$ & 11 & 21 & 0 & 13 & 45 \\
\hline $\mathbf{2 0 0 9}$ & 9 & 28 & 0 & 14 & 51 \\
\hline $\mathbf{2 0 1 0}$ & 7 & 23 & 0 & 24 & 54 \\
\hline $\mathbf{2 0 1 1}$ & 5 & 18 & 0 & 24 & 47 \\
\hline $\mathbf{2 0 1 2}$ & 6 & 9 & 0 & 32 & 47 \\
\hline $\mathbf{2 0 1 3}$ & 10 & 0 & 0 & 53 & 63 \\
\hline $\mathbf{2 0 1 4}$ & 9 & 0 & 0 & 47 & 56 \\
\hline $\mathbf{2 0 1 5}$ & 22 & 0 & 0 & 47 & 69 \\
\hline $\mathbf{2}$ & & & & &
\end{tabular}

\subsection{Sample selection and source of data}

Based on the richness, coverage and comprehensiveness of the research results, this paper chooses the main board of Shenzhen Stock Exchange, SME board and GEM listed companies from 2013 to 2015. The data are from CSMAR and Shenzhen Stock Exchange Information disclosure integrity files, and use Excel and SPSS 22.0 software for data processing. After excluding ST companies, financial industry companies, data outliers, and incomplete data, 3860 samples were obtained, 1352 in 2013, 1318 in 2014, and 1190 in 2015. The sample includes 16 industries.

\subsection{The definition of variables}

In this paper, Tobin's Q is used as the substitute variable of the company's value, and the annual information disclosure evaluation result of Shenzhen Stock Exchange is the substitute variable of information disclosure quality.

Meanwhile, it introduced 9 controlled variables including the scale of ownership, the size of the board of directors, the proportion of independent directors in the board of directors, the unity of the two positions, company size, asset-liability ratio, growth, annual dummy variables and industry dummy variables. As shown in Table 3. 
Table 3 Variable Schedules

\begin{tabular}{|c|c|c|c|}
\hline \\
\hline & Name of the variables & $\begin{array}{l}\text { Symbol of } \\
\text { the variable }\end{array}$ & Explanation of variables \\
\hline $\begin{array}{l}\text { Explained } \\
\text { variable }\end{array}$ & Company Value & Tobin's Q & $\begin{array}{l}\text { (Price } \times \text { Number of tradable shares }+ \text { Net assets per } \\
\text { share } \times \text { Number of non }- \text { circulating shares }+ \text { Book } \\
\text { value of liabilities }) / \text { Total assets }\end{array}$ \\
\hline $\begin{array}{l}\text { Explanatory } \\
\text { variables }\end{array}$ & Disclosure quality & Quality & $\begin{array}{l}\text { Shenzhen Stock Exchange's annual information } \\
\text { disclosure evaluation results, } A=4, B=3, C=2, D=1 \text {. }\end{array}$ \\
\hline \multirow{9}{*}{$\begin{array}{c}\text { Control } \\
\text { variables }\end{array}$} & Equity concentration & $\mathrm{CR}_{1}$ & $\begin{array}{l}\text { Number of shares held by the largest shareholder / } \\
\text { Total number of shares }\end{array}$ \\
\hline & Board size & Bordsize & Number of Board Members \\
\hline & $\begin{array}{l}\text { Proportion of } \\
\text { Independent Directors in } \\
\text { the Board of Directors }\end{array}$ & INDR & $\begin{array}{l}\text { The proportion of the number of independent directors } \\
\text { in the board of directors. }\end{array}$ \\
\hline & Two-in-one & CEO & $\begin{array}{l}\text { Whether the chairman and general manager of the } \\
\text { company are the same person. } \mathrm{Yes}=1 ; \mathrm{No}=2 \text {. }\end{array}$ \\
\hline & Company Size & Size & $\begin{array}{l}\text { The natural logarithm of the total assets of the } \\
\text { company at the end of the period. }\end{array}$ \\
\hline & asset-liability ratio & Lev & $\begin{array}{l}\text { Total liabilities at the end of the year / Total assets at } \\
\text { the end of the year }\end{array}$ \\
\hline & Growth & Growth & $\begin{array}{l}\text { Net profit growth rate }=(\text { Net profit for this year }- \text { Net } \\
\text { profit last year }) / \text { Net profit last year }\end{array}$ \\
\hline & Dummy variable of year & Year & Involving 3 years, set up 2 annual dummy variable. \\
\hline & $\begin{array}{l}\text { Dummy variable of } \\
\text { industry }\end{array}$ & Industry & $\begin{array}{l}\text { Involving } 16 \text { industry classification, set } 15 \text { industry } \\
\text { dummy variables. }\end{array}$ \\
\hline
\end{tabular}

\section{Research assumptions and models}

Based on the above analysis, this paper assumes that the quality of information disclosure and the value of listed companies have a significant positive correlation, and uses the multiple regression analysis. Therefore, the following model was constructed for testing:

$$
\begin{aligned}
\text { Tobin's } Q= & a+\beta_{1} \text { Quality }+\beta_{2} \text { Size }+\beta_{3} \text { Lev }+\beta_{4} \text { Growth }+\beta_{5} C R_{1} \\
& +\beta_{6} \text { Bordsize }+\beta_{7} \text { INDR }+\beta_{8} C E O+\beta_{9} \text { Industry }+\beta_{10} \text { Year }+\varepsilon
\end{aligned}
$$

\section{Empirical Test Results and Analysis}

\subsection{Descriptive statistics}

From Table 4 we can see that in 2013-2015, the average of the information disclosure evaluation results for the sample companies in the Shenzhen Stock Exchange in the integrity is 3.12, the standard deviation is 0.58 . It reveals that the overall level of information disclosure is in good condition, and the overall quality of information disclosure is high. The difference between the maximum and minimum values of Tobin's $Q$ is 9.86 , while the mean is only 2.92, which indicates that the corporate value gap between the sample enterprises selected in this paper is large and not at the same level.

Table 4 Sample descriptive statistics

\begin{tabular}{|c|r|r|r|r|r|r|}
\hline & Number & $\begin{array}{c}\text { Minimum } \\
\text { Value(M) }\end{array}$ & $\begin{array}{c}\text { The } \\
\text { Maximum(X) }\end{array}$ & $\begin{array}{c}\text { Average Value } \\
(\boldsymbol{E})\end{array}$ & $\begin{array}{c}\text { Standard } \\
\text { Deviation }\end{array}$ & Variance \\
\hline Tobin's $\boldsymbol{Q}$ & 3860 & 0.84 & 10.7 & 2.9152 & 1.72389 & 2.972 \\
\hline Quality & 3860 & 1 & 4 & 3.12 & 0.577 & 0.332 \\
\hline Size & 3860 & 18.59 & 27.14 & 21.8435 & 1.06048 & 1.125 \\
\hline Growth & 3860 & -1581.48 & 1309.16 & 5.8486 & 165.7040 & 27457.83 \\
\hline Lev & 3860 & 0.8 & 91.01 & 39.0225 & 20.22464 & 409.036 \\
\hline CR $_{\mathbf{1}}$ & 3860 & 3.62 & 89.99 & 34.2185 & 14.46488 & 209.233 \\
\hline Bordsize & 3860 & 4 & 18 & 8.48 & 1.622 & 2.63 \\
\hline INDR & 3860 & 18.18 & 71.43 & 37.4972 & 5.58538 & 31.196 \\
\hline CEO & 3860 & 1 & 2 & 1.69 & 0.461 & 0.213 \\
\hline Effective $\boldsymbol{N}$ & 3860 & & & & & \\
\hline
\end{tabular}




\subsection{Correlation analysis}

Considering that multicollinearity may be an issue pertaining to sample variables, the Spearman correlation of the sample variables is analyzed. From the overall sample correlation analysis in Table 5 , it can be seen that there is a significant positive correlation between information disclosure quality and corporate value Tobin's Q [5]. That is, after controlling the interaction between information disclosure quality and corporate value, the improvement of information disclosure quality can significantly improve company value.

Table 5 Spearman correlations

\begin{tabular}{|c|c|c|c|c|c|c|c|c|c|c|}
\hline \multicolumn{2}{|c|}{ Spearman's rho } & \multirow{2}{*}{$\begin{array}{l}1 \\
1\end{array}$} & \multirow{2}{*}{$\begin{array}{c}2 \\
.038^{*}\end{array}$} & \multirow{2}{*}{$\begin{array}{c}3 \\
-.523 * *\end{array}$} & \multirow{2}{*}{$\begin{array}{c}4 \\
.120^{* *}\end{array}$} & \multirow{2}{*}{$\begin{array}{c}5 \\
-.513^{* *}\end{array}$} & \multirow{2}{*}{$\begin{array}{c}6 \\
-.074^{* *}\end{array}$} & \multirow{2}{*}{$\begin{array}{c}7 \\
-.185^{* *}\end{array}$} & \multirow{2}{*}{$\begin{array}{c}\boldsymbol{8} \\
.069^{* *}\end{array}$} & \multirow{2}{*}{$\begin{array}{c}9 \\
-.132 * *\end{array}$} \\
\hline $\begin{array}{c}1 . \\
\text { Tobin's }\end{array}$ & $\begin{array}{c}\text { Correlation } \\
\text { Coefficient }\end{array}$ & & & & & & & & & \\
\hline$Q$ & $\begin{array}{c}\text { Sig. } \\
\text { (2-tailed) }\end{array}$ & . & 0.018 & 0 & 0 & 0 & 0 & 0 & 0 & 0 \\
\hline \multirow[t]{2}{*}{$\begin{array}{c}2 . \\
\text { Quality }\end{array}$} & $\begin{array}{c}\text { Correlation } \\
\text { Coefficient }\end{array}$ & $.038^{*}$ & 1 & $.123^{* *}$ & $.049 * *$ & $-.107 * *$ & $.082 * *$ & $.063 * *$ & -0.025 & 0.027 \\
\hline & $\begin{array}{c}\text { Sig. } \\
\text { (2-tailed) }\end{array}$ & 0.018 & . & 0 & 0.002 & 0 & 0 & 0 & 0.125 & 0.088 \\
\hline \multirow[t]{2}{*}{ 3. Size } & $\begin{array}{l}\text { Correlation } \\
\text { Coefficient }\end{array}$ & $-.523 * *$ & $.123 * *$ & 1 & $.045^{* *}$ & $.572 * *$ & $.098^{* *}$ & $.225 * *$ & $-.056^{* *}$ & $.160 * *$ \\
\hline & $\begin{array}{c}\text { Sig. } \\
\text { (2-tailed) }\end{array}$ & 0 & 0 & . & 0.005 & 0 & 0 & 0 & 0 & 0 \\
\hline \multirow[t]{2}{*}{$\begin{array}{c}4 . \\
\text { Growth }\end{array}$} & $\begin{array}{l}\text { Correlation } \\
\text { Coefficient }\end{array}$ & $.120^{* *}$ & $.049 * *$ & $.045^{* *}$ & 1 & 0.022 & -0.022 & -0.008 & -0.01 & -0.02 \\
\hline & $\begin{array}{c}\text { Sig. } \\
\text { (2-tailed) }\end{array}$ & 0 & 0.002 & 0.005 & . & 0.172 & 0.17 & 0.631 & 0.528 & 0.223 \\
\hline \multirow[t]{2}{*}{ 5. Lev } & $\begin{array}{c}\text { Correlation } \\
\text { Coefficient }\end{array}$ & $-.513 * *$ & $-.107 * *$ & $.572 * *$ & 0.022 & 1 & $.049 * *$ & $.141 * *$ & $-.034 *$ & $.082 * *$ \\
\hline & $\begin{array}{c}\text { Sig. } \\
\text { (2-tailed) }\end{array}$ & 0 & 0 & 0 & 0.172 & . & 0.002 & 0 & 0.037 & 0 \\
\hline \multirow[t]{2}{*}{ 6. $C R_{1}$} & $\begin{array}{c}\text { Correlation } \\
\text { Coefficient }\end{array}$ & $-.074 * *$ & $.082 * *$ & $.098 * *$ & -0.022 & $.049 * *$ & 1 & $-.051 * *$ & 0.026 & 0.01 \\
\hline & $\begin{array}{c}\text { Sig. } \\
\text { (2-tailed) }\end{array}$ & 0 & 0 & 0 & 0.17 & 0.002 & . & 0.001 & 0.104 & 0.546 \\
\hline \multirow[t]{2}{*}{$\begin{array}{c}7 . \\
\text { Bordsize }\end{array}$} & $\begin{array}{l}\text { Correlation } \\
\text { Coefficient }\end{array}$ & $-.185^{* *}$ & $.063 * *$ & $.225^{* *}$ & -0.008 & $.141 * *$ & $-.051 * *$ & 1 & $-.633 * *$ & $.200 * *$ \\
\hline & $\begin{array}{c}\text { Sig. } \\
\text { (2-tailed) }\end{array}$ & 0 & 0 & 0 & 0.631 & 0 & 0.001 & & 0 & 0 \\
\hline \multirow[t]{2}{*}{ 8. INDR } & $\begin{array}{l}\text { Correlation } \\
\text { Coefficient } \\
\end{array}$ & $.069 * *$ & -0.025 & $-.056 * *$ & -0.01 & $-.034 *$ & 0.026 & $-.633^{* *}$ & 1 & $-.141 * *$ \\
\hline & $\begin{array}{c}\text { Sig. } \\
\text { (2-tailed) }\end{array}$ & 0 & 0.125 & 0 & 0.528 & 0.037 & 0.104 & 0 & . & 0 \\
\hline \multirow[t]{2}{*}{ 9. CEO } & $\begin{array}{l}\text { Correlation } \\
\text { Coefficient } \\
\end{array}$ & $-.132 * *$ & 0.027 & $.160 * *$ & -0.02 & $.082 * *$ & 0.01 & $.200 * *$ & $-.141 * *$ & 1 \\
\hline & $\begin{array}{c}\text { Sig. } \\
\text { (2-tailed) }\end{array}$ & 0 & 0.088 & 0 & 0.223 & 0 & 0.546 & 0 & 0 & . \\
\hline
\end{tabular}

\subsection{Regression test}

From the model summary Table 6 , we can see the fitting of the model. Since the complex correlation coefficient $\mathrm{R}$ is 0.675 , the determination coefficient $\mathrm{R}$ is 0.455 and the adjusted $\mathrm{R}$ is 0.452 , which indicates that the fitting degree of the regression equation is acceptable. 
Table 6 Model Summary ${ }^{\mathrm{i}}$

\begin{tabular}{|c|c|c|c|c|c|c|c|c|c|}
\hline \multirow[b]{2}{*}{ Model } & \multirow[b]{2}{*}{$\boldsymbol{R}$} & \multirow[b]{2}{*}{$\begin{array}{c}R \\
\text { Square }\end{array}$} & \multirow[b]{2}{*}{$\begin{array}{c}\text { Adjusted } R \\
\text { Square }\end{array}$} & \multirow[b]{2}{*}{$\begin{array}{l}\text { Std. Error of the } \\
\text { Estimate }\end{array}$} & \multicolumn{3}{|c|}{ Change Statistics } & \multicolumn{2}{|c|}{ Change Statistics } \\
\hline & & & & & $\begin{array}{c}\text { R Square } \\
\text { Change }\end{array}$ & $\begin{array}{c}F \\
\text { Change }\end{array}$ & $d f 1$ & $d f 2$ & $\begin{array}{c}\text { Sig. F } \\
\text { Change }\end{array}$ \\
\hline 8 & $.675^{\mathrm{h}}$ & 0.455 & 0.452 & 1.27643 & 0.001 & 3.862 & 1 & 3835 & 0.049 \\
\hline
\end{tabular}

From Table 7, it can be seen that the quality of information disclosure has a significant positive correlation with the value of Tobin $\mathrm{Q}(\mathrm{t}=4.345, \mathrm{P}=0.000<0.100)$ at the $1 \%$ significance level, which confirms the objective of this paper. In addition, the growth rate of net profit, the proportion of independent directors, the proportion of the largest shareholder holdings and the value of listed companies that Tobin Q also has a positive correlation. In contrast, the total assets of the natural logarithm of the company size and asset-liability ratio are negative correlated to the value of listed companies which is the Tobin's Q value.

At the same time, it can be found that the influence of industry dummy variables on corporate value can't be ignored. Therefore, it is concluded from the empirical results that it is necessary to implement the requirements of information disclosure by industry [6].

Table 7 Coefficients ${ }^{\mathrm{a}}$

\begin{tabular}{|c|c|c|c|c|c|c|c|c|}
\hline \multirow{2}{*}{\multicolumn{2}{|c|}{ Model }} & \multicolumn{2}{|c|}{$\begin{array}{c}\text { Unstandardized } \\
\text { Coefficients }\end{array}$} & \multirow{2}{*}{$\begin{array}{c}\text { Standardized } \\
\text { Coefficients } \\
\text { Beta }\end{array}$} & \multirow[t]{2}{*}{$t$} & \multirow[t]{2}{*}{ Sig. } & \multicolumn{2}{|c|}{$\begin{array}{l}\text { Collinearity } \\
\text { Statistics }\end{array}$} \\
\hline & & $B$ & Std. Error & & & & Tolerance & VIF \\
\hline \multirow[t]{8}{*}{8} & (Constant) & 15.681 & 0.583 & & 26.911 & 0 & & \\
\hline & Size & -0.6 & 0.026 & -0.369 & -23.211 & 0 & 0.562 & 1.779 \\
\hline & LeV & -0.017 & 0.001 & -0.204 & -12.729 & 0 & 0.553 & 1.809 \\
\hline & Quality & 0.163 & 0.037 & 0.054 & 4.345 & 0 & 0.906 & 1.103 \\
\hline & Growth & 0.001 & 0 & 0.049 & 4.114 & 0 & 0.987 & 1.014 \\
\hline & INDR & 0.012 & 0.004 & 0.039 & 3.195 & 0.001 & 0.975 & 1.026 \\
\hline & CR1 & 0.005 & 0.001 & 0.04 & 3.269 & 0.001 & 0.949 & 1.054 \\
\hline & CEO & -0.09 & 0.046 & -0.024 & -1.965 & 0.049 & 0.946 & 1.057 \\
\hline
\end{tabular}

In this paper, multiple collinearity tests are performed. The variance expansion factor VIF of each explanatory variable is between 1.0 and 2.0, both less than 10. Moreover, the tolerance of each explanatory variable is greater than 0.1 . It can be judged that there is no multicollinearity problem between explanatory variables.

Based on the above analysis, we can see that the goodness of fit is 0.452 and $\mathrm{F}$ is significant at the level of $1 \%$. The conclusion can be drawn that the regression model has good fitting [7]. After comparing the regression coefficients and the t-values of the Shenzhen Stock Exchange on the main board, SME board, and GEM, we can see that these sample data are almost falls at the $1 \%$ significance level, the quality of information disclosure of listed companies is positively related to the value of companies.

\subsection{Robustness test}

In this paper, the earnings per share (EPS) is chosen as the substitute variable of the company's value, and the model robustness test is carried out. As shown in Table 8, there is a significant positive correlation between the level of information disclosure and firm value. This is consistent with the result of Tobin's Q value as a substitute variable of firm value, which indicates that the multiple regression model constructed in this paper is effective and robust, and the empirical results will not change with the change of parameters.

Table 8 Model Summary ${ }^{i}$

\begin{tabular}{|c|c|c|c|c|c|c|c|c|c|}
\hline \multirow[b]{2}{*}{ Model } & \multirow[b]{2}{*}{$\boldsymbol{R}$} & \multirow{2}{*}{$\begin{array}{c}R \\
\text { Square }\end{array}$} & \multirow{2}{*}{$\begin{array}{c}\text { Adjusted R } \\
\text { Square }\end{array}$} & \multirow{2}{*}{$\begin{array}{l}\text { Std. Error of the } \\
\text { Estimate }\end{array}$} & \multicolumn{3}{|c|}{ Change Statistics } & \multicolumn{2}{|c|}{ Change Statistics } \\
\hline & & & & & $\begin{array}{c}\text { R Square } \\
\text { Change }\end{array}$ & $\begin{array}{c}F \\
\text { Change }\end{array}$ & $d f 1$ & $d f 2$ & $\begin{array}{c}\text { Sig. F } \\
\text { Change }\end{array}$ \\
\hline 8 & $.543^{\mathrm{h}}$ & 0.295 & 0.291 & 0.35494 & 0.001 & 4.217 & 1 & 3836 & 0.04 \\
\hline \multicolumn{10}{|c|}{ h. Predictors: (Constant), Year, Industry, Quality, Size, Growth, Lev, CR ${ }^{1}$, Bordsize, INDR, CEO. } \\
\hline
\end{tabular}




\section{Conclusion}

In summary, this paper based on the status quo and research conclusions put forward the following four suggestions:(1) Improve the information disclosure system, strengthen voluntary disclosure of information;(2) Strengthen discipline, rewards and punishments simultaneously. Prevention as the main means;(3) The establishment of intermediary rating agencies, the introduction of third - party evaluation system [8];(4) To cultivate the information needs of investors and guide the improvement of information disclosure. From the empirical results of this paper can be drawn: the company value increases with the company's information disclosure quality. Therefore, the real corporate value of listed companies can be achieved by narrowing the information asymmetry with investors [9]. In order to obtain good economic results, not only beneficial to investors, is also conducive to business.

\section{References}

[1] Meek, G.K., Roberts, C.B. and Gray, S.J. Factors Influencing Voluntary Annual Report Disclosure by U.S., U.K. And Continental European Multinational Corporations [J]. Journal of International Business Studies.1995, 555-572.

[2] Zong-xin ZHANG. The quality of information disclosure of listed companies and investor protection research [M]. Beijing. China Financial Publishing House, 2009: 148-172.

[3] Guo-hui CHEN, Hai-wen HAN. Value Effect Test of Voluntary Information Disclosure [J]. 2010.5 (5): 61-65.

[4] Shou-fu XU, Long-bing XU. Quality of Information Disclosure and Deviation of Capital Market Valuation [J]. Accounting Research, 2015 (1): 40-47.

[5] Cheng-rui ZHANG. Effectiveness of Corporate Information Disclosure on Investor Protection: An Empirical Study on Annual Report Disclosure of Chinese Listed Companies from 2001 to 2013 [J]. Economic Review, 2016 (1): 132-146.

[6] Ying ZHAO, Shu LI. The Development and Inspiration of the Value Effect of Voluntary Disclosure Capital Market in Foreign Countries [J]. Finance and Accounting Newsletter, 2015 (3): $93-96$

[7] Jian-jun DU, Ling-ling DAI. Study on the Impact of Listed Company's Information Disclosure Quality on Firm Value [J]. Jilin Business School, 2016, 32 (1); 37-42.

[8] Booch G, Rumbaugh J, Jacobson I. Unified Modeling Language User Guide, (The 2nd Edition) (Addison-Wesley Object Technology Series) [M]. Addison-Wesley Professional, 2005.

[9] Mei-ling Xu, Chen-lei Guo. The Empirical Study on the Relationship between the Quality of Information Disclosure and the Value of the Company [J]. North China Economics: Comprehensive Edition, 2010 (15): 10-14. 